\title{
In memoriam
}

\section{Vlado Jukić}

Prof. dr. sc., dr. med. / Professor, MD, PhD

(23. lipnja 1951., Osoje - 3. ožujka 2019., Zagreb)

(June 23, 1951, Osoje - March 3, 2019, Zagreb)

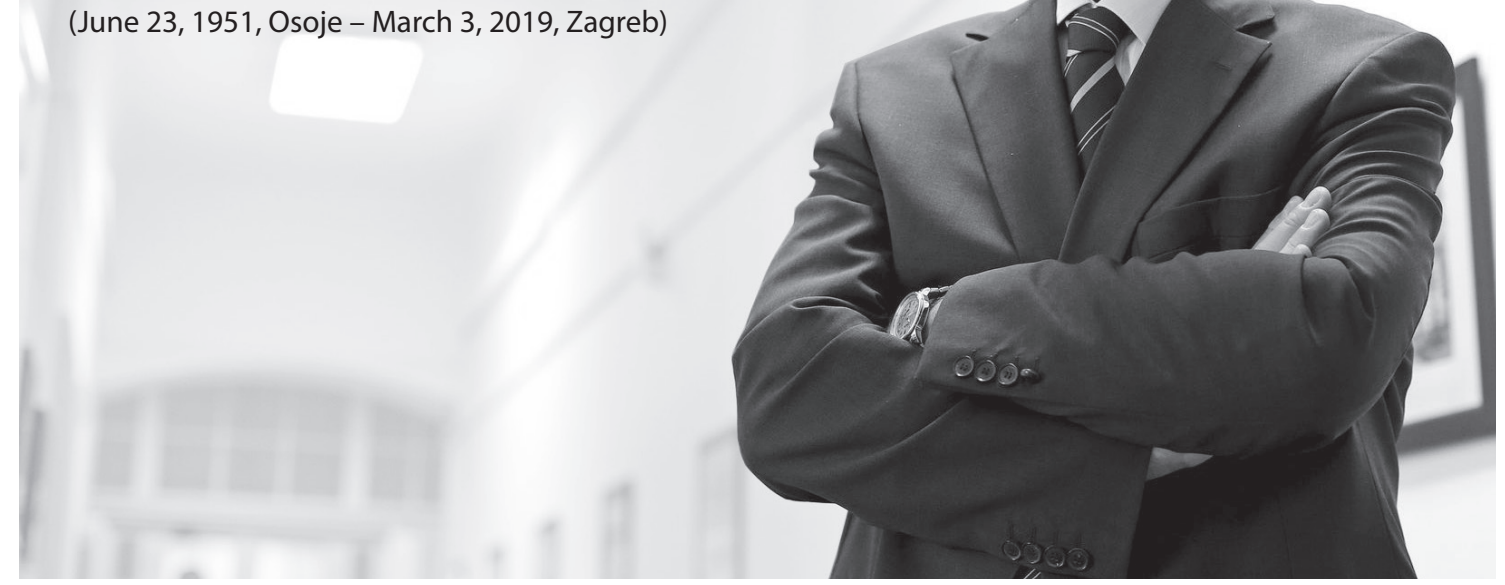

Umro je Vlado Jukić. Naglo i iznenadno. Te riječi zvuče nestvarno, a ta se činjenica čini nemogućom. No ipak je to stvarno i to se dogodilo. Zauvijek nas je napustio prof. dr. sc. Vlado Jukić. Otišao je onako kako je i živio, radio, razmišljao - žestoko i brzo. A nas je sve ostavio u nevjerici i šoku.

Vlado Jukić rođen je 23. lipnja 1951. godine u malom hercegovačkom selu Osoje pokraj Posušja, od petero djece, kao 3. dijete majke Jage i oca Dominika. U obližnjem Posušju završio je osnovnu školu i gimnaziju.

Godine 1970. upisao se na Medicinski fakultet Sveučilišta u Zagrebu, na kojemu je diplomirao 1976. Nakon završenog obveznog liječničkog staža u Medicinskom centru Koprivnica, kratkotrajno je radio u Domu zdravlja Poreč i Medicinskom centru Sisak.

Godine 1978. zaposlio se u Neuropsihijatrijskoj bolnici „Dr. Ivan Barbot“ u Popovači, gdje je 1979. započeo, a 1982. završio specijalizaciju iz psihijatrije. Često je govorio kako ga je psihijatrija zanimala još od studentskih dana. Želio
Vlado Jukić has died. Suddenly and shockingly. These words sound unreal, and this fact seems impossible. But they are true, and this has really happened. Prof Vlado Jukić, MD, PhD, has left us forever. He departed the way he lived, worked and thought - quickly and intensely - leaving all of us in shock and disbelief.

Vlado Jukić was born on June 23, 1951 in the small Herzegovienian village of Osoje near Posušje as the third of five children of his mother Jaga and father Dominik. He finished primary and secondary school in the nearby town of Posušje.

In 1970 he enrolled at the University of Zagreb Medical School, from which he graduated in 1976. After completing his mandatory medical residency at the Koprivnica Medical Centre, he briefly worked at the Poreč Medical Centre and Sisak Medical Centre.

In 1978 he started working at the Dr Ivan Barbot Neuropsychiatry Hospital in the town of Popovača, where he started his residency in psychiatry in 1979 and finished it in 1982. He often said psychiatry interested him ever since he was a student of medicine. He wanted to help people with mental issues, not just as a physician. He demon- 
je pomagati osobama s duševnim smetnjama ne samo kao liječnik. To je dokazivao tijekom cijeloga radnog vijeka. Znao je reći „za te ljude treba se boriti, jer često oni to sami ne mogu“. Poznate su njegove borbe $s$ administracijama i sustavima u kojima je izvojevao i mnoge pobjede. Tako je "vratio“ na posao shizofrenog bolesnika koji je dobio otkaz, a kasnije ga i „umirovio". Omogućio je promjenu oporuka kojima su duševni bolesnici izostavljeni iz nasljeđivanja. Pomogao je da shizofreni bolesnik koji je u stanju neubrojivosti usmrtio majku naslijedi obiteljsku mirovinu. I još mnogo, mnogo toga.

U Kliniku za psihijatriju KBC-a Zagreb prelazi 1986., najprije u Centar za krizna stanja, a potom na Odjel muške psihijatrije. Godine 1994. prelazi u Psihijatrijsku bolnicu Vrapče i postaje njezin ravnatelj. Pod njegovim vodstvom Bolnica se obnavlja i mijenja nazive, prvo u Klinička psihijatrijska bolnica Vrapče, a zatim u Klinika za psihijatriju Vrapče. Po riječima njegove zamjenice, doc. dr. sc. Petrane Brečić, ali i svih kolega u toj ustanovi, bio je „najuspješniji i najdugovječniji vrapčanski ravnatelj“.

U 25 godina on je izgradnjom, dogradnjom i adaptacijom zgrada u potpunosti izmijenio arhitektonsku sliku Bolnice. Obnovio ju je iz temelja i izgradio nove zgrade. Tako je, kronološki gledano, izgrađena plinska kotlovnica, obnovljene su zgrade „šestice“ i „petice“, dograđena je i adaptirana zgrada „četvorke“. Zatim je sanirana glavna zgrada, ulaz u Bolnicu („kameni portal“), obnovljena „devetka“i i "jedanaestica“. Poslije su izgrađene galerija „Slava Raškaj"i kapelica, adaptirana je velika bolnička dvorana u Centar za edukaciju, obnovljene su "osmica“ i zgrade u kojima su smješteni Centar za radno-okupacijsku terapiju i rehabilitaciju te Muzej bolnice Vrapče. Posljednji sagrađen Zavod za forenzičku psihijatriju otvoren je potkraj 2018. godine. Uz njegovo je otvaranje prof. Jukić organizirao međunarodni simpozij na temu forenzičke psihijatrije na početku 21. stoljeća, u okviru kojega je održan i okrugli stol strated that throughout his career. Prof Jukić was known to say "we have to fight for these people, because they cannot do it on their own". His battles with administration and systems are wellknown, and he won many victories. Among them are successfully returning a schizophrenic patient to work after he had been fired and then arranging his retirement later on. He worked on changing last wills and testaments where mental health patients were left out of the inheritance. He helped a schizophrenic patient who killed his mother in a mentally unsound state inherit the family pension, and many, many other people besides.

He transferred to the Psychiatry Clinic of the Zagreb Clinical Hospital Centre in 1986, initially to the Crisis Centre and later to the Male Psychiatry Ward. Under his leadership, the Hospital was renovated and changed its name, first to the Vrapče Clinical Psychiatric Hospital and then to the Vrapče Psychiatry Clinic. According to the words of his deputy director, Dr Petrana Brečić, MD, $\mathrm{PhD}$, but also all his colleagues in that institution, he was the "most successful and longest-acting director of the Vrapče Psychiatry Clinic".

Over 25 years in which he built, expanded and adapted hospital buildings, he completely changed the architectural picture of the Hospital. He renovated it from the very foundations and added new buildings. Chronologically listed, this included the construction of the boiler house, renovations of buildings "six" and "five" and expansion and adaptation of building "four". This was followed by refurbishment of the main building and the entrance to the Hospital (the "stone portal") and renovation of buildings "nine" and "eleven". Later on, the Slava Raškaj Gallery and chapel were built, the great hospital hall was adapted to be the Education Centre and building "eight" and the buildings housing the Centre for Occupational Therapy and Rehabilitation as well as the Vrapče Hospital Museum were renovated. Finally, the Institute for Forensic Psychiatry was opened near the end of 2018. To accompany the opening of the institute, Prof Jukić organized an international symposium on the topic of forensic psychiatry at the start of the $21^{\text {st }}$ century, which included a round table discussion on forensic psy- 
o forenzičkoj psihijatriji u Hrvatskoj. To je smatrao „vrhuncem svoje stručne karijere“.

Da je samo obnovio i izgradio Bolnicu bio bi uspješan. Ali, on je bio veliki ravnatelj jer je unaprijedio sve aktivnosti Bolnice, profilirao ju je kao u mnogočemu najznačajniju psihijatrijsku ustanovu u nas. Zapošljavao je mlade, omogućavao im specijalizacije, usavršavanja, edukacije. Poticao je stručni i znanstveni rad. Brojnim kolegama omogućio je izbor u znanstvena i znanstveno-nastavna zvanja. Pozivao je na objavljivanje radova, sudjelovanje na stručnim skupovima, medijske istupe. Na godišnjicu osnivanja bolnice (15. studenoga) godinama je organizirao uspješne stručne i znanstvene skupove koji su popraćeni i zbornikom radova. Neke od tih knjiga su i danas tražena literatura. Također je organizirao tribine Film i psihijatrija, koje su poprimile kultni status. Osnovao je i Muzej Bolnice Vrapče.

Završio je poslijediplomski studij iz Forenzičke psihijatrije (1980.-1981.) i odslušao sva predavanja na poslijediplomskim studijima iz psihoterapije i socijalne psihijatrije (1980.-1982.). Završio je edukaciju iz grupne psihoterapije (kod prof. E. Klaina, 1978.-1986.) te obiteljsku psihoterapiju (kod doc. Vlatković, 1986.1989.).

Magistrirao je 1989. godine s temom „Prekid stacionarnog liječenja i čuvanja psihički abnormalnih delinkvenata" (mentor prof. dr. sc. Rudolf Turčin). Doktorirao je s temom „Utjecaj stresova na kliničku sliku posttraumatskog stresnog poremećaja u hrvatskih ratnih stradalnika" (mentor prof. dr. sc. Eduard Klain) 1997. godine.

Na Medicinski fakultet Sveučilišta u Zagrebu primljen je kao asistent 1990. u tadašnju Katedru za psihijatriju i medicinsku psihologiju (danas Katedra za psihijatriju i psihološku medicinu). Docent je postao 1998., izvanredni profesor 2004., redoviti profesor 2010., a redoviti profesor u trajnom zvanju 2016. chiatry in Croatia. He considered this "the peak of his professional career".

If he had just renovated and built the Hospital, he would have been considered a successful director. But he was a truly great hospital director because he also improved all hospital activities and established it as the in many ways most significant psychiatric institution in the country. He employed young people and enabled them to get residencies, training and education. He encouraged expert and scientific engagement. There were numerous colleagues whom he helped in selection for scientific and teaching positions. He encouraged publication of papers, participation on scientific conferences and engagement in the media. On the anniversary of the foundation of the Hospital (November 15) he successfully organized annual expert and scientific conferences that were accompanied by a book of conference proceedings. Some of these books are still popular and sought-after today. Additionally, he organized a series of public discussions, Film and Psychiatry, which achieved cult status. He also founded the Vrapče Hospital Museum.

Prof Jukić completed his postgraduate studies in Forensic Psychiatry (1980-1981) and attended all the lectures at the postgraduate courses in psychotherapy and social psychiatry (1980-1982). He completed education courses in group psychotherapy (with Prof E. Klain, 1978-1986) and family psychotherapy (with Assistant Prof Vlatković, 1986-1989).

He won his master's degree in 1989 with the title "Ending Infirmary Treatment and Safeguarding Psychologically Abnormal Delinquents" (mentored by Prof Rudolf Turčin, MD, PhD). His doctoral thesis was titled "Influence of Stresses on the Clinical Picture of Posttraumatic Stress Disorder in Croatian War Victims" (mentored by Prof Eduard Klain, MD, Phd) and was completed in 1997.

The University of Zagreb Medical School appointed him as an instructor in 1990 at the Department of Psychiatry and Medical Psychology (today called the Department of Psychiatry and Psychological Medicine). He became an assistant professor in 1998, an associate professor in 2004, 
Na Medicinskom fakultetu u Zagrebu sudjelovao je u dodiplomskoj nastavi predmeta „Psihijatrija“, „Medicinska etika“, „Ratna medicina“, „Forenzička psihijatrija“. Bio je voditelj predmeta „Psihologija sestrinstva“ na Studiju sestrinstva.

U poslijediplomskoj nastavi sudjelovao je u više predmeta poslijediplomskih studija „Forenzična psihijatrija“ (od 1998. do 1999.), „Psihoterapija“ (od 1998.), „Socijalna psihijatrija“ (od 1998. do 2004.), „Menadžment u zdravstvu“ (od 2000.). „Klinička farmakologija“ (od 1998.), "Opće kompetencije liječnika specijalista" (od 2014.). U poslijediplomskom specijalističkom studiju „Psihijatrija“ (od 2014.) bio je nositelj predmeta „Bolesti ovisnosti“, „Forenzička psihijatrija“ $i$ „Povijest psihijatrije“.

Na Pravnom fakultetu Sveučilišta u Zagrebu, na studiju socijalnog rada bio je nositelj predmeta „Socijalna psihijatrija“ $i$ „Socijalni rad s ovisnicima“, a na Edukacijsko-rehabilitacijskom fakultetu Sveučilišta u Zagrebu nositelj kolegija „Forenzička psihijatrija“. Na Hrvatskim studijima Sveučilišta u Zagrebu na studiju psihologije bio je nositelj kolegija „Opća psihopatologija“ i "Specijalna psihopatologija“ te izbornog kolegija „Forenzička psihijatrija“.

Na Zdravstvenom veleučilištu Zagreb bio je nositelj kolegija „Menadžment u zdravstvu“ (od 2007. do 2015.).

Na Medicinskom fakultetu Sveučilišta u Mostaru sudjelovao je u dodiplomskoj i poslijediplomskoj nastavi te je bio predsjednik Etičkog povjerenstva i član Povjerenstva za ocjenu magistarskih radova i doktorskih disertacija.

Na Filozofskom fakultetu Sveučilišta u Zagrebu u studiju „Klinička psihologija“ bio je nositelj predmeta „Biološki pristupi u liječenju psihijatrijskih bolesti“ od 2011. Na Farmaceutsko-biokemijskom fakultetu Sveučilišta u Zagrebu na studiju „Klinička farmacija“ bio je nositelj predmeta „Farmakoterapija duševnih bolesti i poremećaja“. a full professor in 2010 and a tenured full professor in 2016.

At the Zagreb Medical School he participated in teaching on the graduate courses Psychiatry, Medical Ethics, War Medicine and Forensic Psychiatry. He was head of the Psychology in Nursing course at the Nursing Studies.

Prof Jukić participated in teaching numerous postgraduate courses: Forensic Psychiatry (19981999), Psychotherapy (from 1998), Social Psychiatry (1998-2004), Management in Healthcare (since 2014). As part of the Psychiatry postgraduate specialization programme (since 2014) he headed the courses Diseases of Addiction, Forensic Psychiatry and History of Psychiatry.

As part of the social work studies at the University of Zagreb Faculty of Law, he headed the Social Psychiatry and Social Work with Addicts courses, and at the Faculty of Education and Rehabilitation Sciences he headed the Forensic Psychiatry course. At the University of Zagreb Centre for Croatian Studies psychology course he headed General Psychopathology and Special Psychopathology courses and the elective Forensic Psychiatry course.

At the Zagreb Health Studies, he headed the Management in Healthcare course (from 2007 to 2015).

Prof Jukić also participated in graduate and postgraduate teaching at University of Mostar Medical School and was the president of the Ethics Committee and a member of the Commission for the Evaluation of Master Theses and Doctoral Dissertations.

At the University of Zagreb Faculty of Humanities and Social Sciences, he headed the course Biological Approaches in the Treatment of Psychiatric Illnesses as part of the Clinical Psychology study programme since 2011. At the University of Zagreb Faculty of Pharmacy and Biochemistry as part of the Clinical Pharmacy study programme, he headed the course Pharmacotherapy of Mental Illnesses and Disorders.

At his alma mater, he was the secretary of the Department of Psychiatry and Psychological Medicine (1991-1994), a member of the Academic Council 
Na matičnom je fakultetu bio tajnik Katedre za psihijatriju i psihološku medicinu (1991.1994.), član Fakultetskog vijeća (1996.-1998.), član Odbora za studentski standard (1996.1998.), član Etičkog povjerenstva (1998.2002.), član Odbora za sudska mišljenja (2002.2006.), član Povjerenstva za stegovni postupak (od 2012.), pomoćnik pročelnika Katedre i voditelj nastave za predmet „Psihijatrija“ u Klinici za psihijatriju Vrapče (od 2010.).

Bio je mentor u brojnim studentskim diplomskim radovima, magisterijima i doktoratima. Smrt ga je prekinula u mentorstvu tri doktorska rada.

Publicistička je aktivnost prof. Jukića impresivna. To je na neki način i logično, jer je iz njega neprestano izvirala ljubav za pisanom riječju. Knjige je čitao, volio, kupovao. Još kao student obožavao je u antikvarijatima tragati za nekom knjigom, pronaći je i kupiti ili samo rezervirati. Od skromnih studentskih prihoda uspijevao je odvojiti dio novaca kako bi kupio neku sebi važnu knjigu. Kasnije je kupovao sve više knjiga i za obiteljsku i za knjižnicu Bolnice. Pisao je puno i poticao druge da pišu.

Iza sebe je ostavio više od 250 stručnih i znanstvenih radova, u domaćim i međunarodnim časopisima, zbornicima i knjigama, više od 100 priopćenja na stručnim skupovima i kongresima te 24 poglavlja u udžbenicima. Objavljene su mu tri monoautorske knjige: Hrvatska psihijatrijska publicistika (2014.), Izgradnja, dogradnje i adaptacije zgrada i drugih infrastrukturnih objekata bolnice Vrapče od 1977. do 2014. godine (2015.) i Psihijatrijske teme za nepsihijatre (2018.). Urednik je 16 stručnih knjiga (među njima i nekoliko temeljnih udžbenika) te 5 popularnoznanstvenih knjiga. Bio je član Uredničkog vijeća Leksikona odgojno-obrazovnih znanosti (2017.).

Jedan je od urednika i prijevoda Jaspersove „Opće psihopatologije“ (2015.), Dijagnostičkog i statističkog priručnika za duševne poremeća-
(1996-1998), the Committee for Student Standards (1996-1998), the Ethics Committee (19982002), the Committee for Court Expert Opinions (2002-2006), a member of the Commission for Disciplinary Procedures (since 2012), Department Head Assistant and course head for the Psychiatry course at the Vrapče Psychiatry Clinic (since 2010).

Prof Jukić mentored numerous student graduation theses, master theses and doctoral dissertations. His death interrupted him in the mentorship of three doctoral dissertations.

The publishing activities of Prof Jukić are impressive. In a way this is to be expected, since he constantly exuded love for the written work. He read, loved and bought books. Even as a student, he loved searching through antique bookshops for a book, finding it and buying or just reserving it. He would always somehow manage to dedicate a part of his meagre student earnings to buying himself an important book. Later he bought more and more books for his family library and the Hospital library as well. He wrote much, and encouraged others to write.

Prof Jukić leaves behind more than 250 professional and scientific papers, published in Croatian and in international journals, conference proceedings and books, more than 100 presentations from conferences and congresses as well as 24 chapters in course books. He published three books as the sole author: Croatian Psychiatric Publishing (2014), Building, Expanding and Adapting Buildings and Other Infrastructural Objects at Vrapče Hospital from 1977 to 2014 (2015) and Psychiatric Topics for Non-psychiatrists (2018). He was an editor for 16 professional books (including a few fundamental course books) and 5 popular science books. He was a member of the Editorial Board of the Lexicon of Education Sciences (2017).

He was also one of the editors of the translation of Jaspers' General Psychopathology (2015), a diagnostic and statistical handbook for mental disorders, fifth edition (DSM-5, 2014), and the MMSE-2 Handbook (2011). Just before he underwent his operation, he managed to complete three manuscripts and send them to the 
je, peto izdanje (DSM-5, 2014.) te Priručnika MMSE-2 (2011.). Neposredno prije nego što je otišao na operaciju uspio je završiti tri rukopisa i uputiti ih u Medicinsku nakladu, kao da je slutio da je smrt toliko blizu.

Napisao je recenzije za više od 30 knjiga i udžbenika.

Bio je član uredništava časopisa „Socijalna psihijatrija“ (od 1994.), „Farmaka“ (1998.-2008.), „Klinička psihologija“ (od 2008.), PLIVAmed. net (od 2014.), „Psychiatria Danubina“ i „Psihoterapija" (od 2016.). Recenzirao je brojne radove za domaće i međunarodne časopise.

Za „Socijalnu psihijatriju“ bio je posebno vezan. „Otkrio“ ju je na studiju, pretplatio se kao mladi liječnik, prve radove objavio je u njoj. Godine 1994. postao je član uredništva i bio među najaktivnijima u tom društvu. U dvadesetogodišnjem razdoblju objavio je najviše članaka u „Socijalnoj psihijatriji“, a vrlo je vjerojatno da je to časopis u kojemu je najčešće i objavljivao svoje radove. Njegovi su rukopisi bili prepoznatljivi, detaljni, s puno podataka, dodataka i fusnota. Te su fusnote katkad bile (pre)duge pa bi ga tehnička urednica našeg časopisa znala zamoliti da od nekih fusnota odustane ili da ih skrati. On je tada rekao kako je sve to važno i da teško može nešto izostaviti. Kao ravnatelj Bolnice (Klinike) poticao je kolege i suradnike da objavljuju u časopisu, a istovremeno je i financijski pomagao njegovo izlaženje. On se zalagao da "Socijalna psihijatrija“ postane službeno glasilo Hrvatskog psihijatrijskog društva te je $s$ pozicije njegova predsjednika pomagao tiskanje časopisa. Bez te pomoći časopis bi se u jednom razdoblju vjerojatno „ugasio“, ali zahvaljujući prije svega prof. Jukiću uspio se održati i nastaviti kontinuirano izlaziti.

Bavio se svakodnevnim kliničkim radom psihijatra praktičara (bio je supspecijalist iz biologijske psihijatrije) i forenzičara (bio je dugogodišnji sudski vještak i supspecijalist iz forenzičke psihijatrije). Zalagao se za destigmatizcaiju
"Medicinska naklada" publishing house, as if he had suspected that death was close at hand.

He wrote reviews for more than 30 books and course books.

He was a member of the Editorial Board of the following journals: Social Psychiatry (from 1994), "Farmaka" (1998-2008), Clinical Psychology (from 2008), PLIVAmed.net (since 2014), Psychiatria Danubina and "Psihoterapija" (since 2016). He peer-reviewed numerous manuscripts for Croatian and international journals.

Prof Jukić was especially attached to the Social Psychiatry journal. He "discovered" it as a student, subscribed to it as a young physician and published his first papers in this journal. He became a member of the Editorial Board in 1994 and was among the most active members. Over the twenty or so years of his career, it was in this journal that he published the highest number of papers and it is very likely that this was the journal where he published most often. His manuscript submissions were easily recognizable, with a wealth of details, data, appendixes and footnotes. These footnotes were sometimes (too) long, and the technical editor of our journal would sometimes ask him to remove or shorten these footnotes. He would then say that all of it was important and that he can hardly leave anything out. As the director of the Vrapče Hospital (Clinic), he encouraged colleagues to publish in the Social Psychiatry journal and provided financial support to the journal as well. He worked to make Social Psychiatry the official journal of the Croatian Psychiatric Association and assisted the publication of the journal as the president of the association. Without his help, it is likely that publication of the journal would have stopped at some point, but primarily thanks to Prof Jukić it has survived and continuously publishes new issues.

Prof Jukić performed the everyday duties of a practicing psychiatrist (he was a subspecialist in biological psychiatry) and forensic expert (he was a long-serving expert court witness and subspecialist in forensic psychiatry). He fought for the de-stigmatization of mental issues, psychiatric patients and members of their families. He participated in changing existing laws and rules and 
psihičkih smetnji, duševnih bolesnika i članova njihovih obitelji. Sudjelovao je u promjeni postojećih i donošenju novih zakona i pravilnika koji su regulirali prava duševnog bolesnika. Bio je pokretač ideje o proglašenju 6. lipnja Danom prava osoba s duševnim smetnjama.

Organizirao je brojne skupove i kongrese. Najvažniji su Ratna psihologija i psihijatrija (predsjednik organizacijskog odbora), Zdravstveni problemi žrtava zlostavljanja u zatvorima i koncentracijskim logorima agresora u ratu protiv Hrvatske 1991./92. godine (član stručnog i organizacijskog odbora), 1. hrvatski psihijatrijski kongres (tajnik), 2., 3. i 4. hrvatski psihijatrijski kongres (član stručnog i organizacijskog odbora), 5. hrvatski psihijatrijski kongres (dopredsjednik), 6. i 7. hrvatski psihijatrijski kongres (predsjednik), 1. do 7. hrvatski psihijatrijski dani (član stručnog odbora), 8. do 15. hrvatski psihijatrijski dani (predsjednik stručnog i organizacijskog odbora), 1. do 12. mostarske psihijatrijske subote (član stručnog odbora).

Bio je član Hrvatskog liječničkog zbora, član stručnih društava HLZ-a (za kliničku psihijatriju, psihoterapiju, forenzičku psihijatriju, biologijsku psihijatriju i kliničku psihofarmakologiju, za alkoholizam i druge ovisnosti, za Alzheimerovu bolest), član Hrvatskog katoličkog liječničkog društva, član European Psychiatrists Association (EPA), International Society for the Investigation of Stress (ISIS), član svjetskog društva za biologijsku psihijatriju, predsjednik Crvenog križa Grada Zagreba (od 2012.), član Odbora za neuroznanost i bolesti mozga pri Razredu za medicinske znanosti HAZU (od 2015.), redoviti član Akademije odgojno obrazovnih znanosti Hrvatske (od 2017.), redoviti član Akademije medicinskih znanosti Hrvatske (od 2018.).

Za psihijatre i sve druge djelatnike u psihijatriji učinio je mnogo, a osobito kada je obnašao dužnost predsjednika Hrvatskog psihijatrijskog društva (od 2010. do 2018.). Bio je i član making new ones regulating the rights of psychiatric patients. He was the initiator of the idea to pronounce the $6^{\text {th }}$ of June as the Rights of Persons with Mental Issues Awareness Day.

He organized numerous conferences and congresses. The most important ones were War Psychology and Psychiatry (president of the organization committee), Health Problems in Victims of Abuse in Prisons and Concentration Camps of the Aggressor in the War against Croatia 1991/92 (member of the expert and organization committee), $1^{\text {st }}$ Croatian Psychiatric Congress (secretary), $2^{\text {nd }}, 3^{\text {rd }}$ and $4^{\text {th }}$ Croatian Psychiatric Congress (member of the expert and organization committee), $5^{\text {th }}$ Croatian Psychiatric Congress (vice-president), $6^{\text {th }}$ and $7^{\text {th }}$ Croatian Psychiatric Congress (president), $1^{\text {st }}$ to $7^{\text {th }}$ Croatian Psychiatric Days (member of the expert committee), $8^{\text {th }}$ to $15^{\text {th }}$ Croatian Psychiatric Days (president of the expert and organization committees), $1^{\text {st }}$ to $12^{\text {th }}$ Psychiatric Saturday in Mostar (member of the expert committee).

He was a member of the Croatian Physicians Association (CPA) and a member of CPA's expert societies (for clinical psychiatry, psychotherapy, forensic psychiatry, biological psychiatry and clinical psychopharmacology, for alcoholism and other addictions, for Alzheimer's disease), a member of the Croatian Catholic Medical Society, a member of the European Psychiatrists Association (EPA), the International Society for the Investigation of Stress (ISIS), the World Federation of Societies of Biological Psychiatry, the president of the City of Zagreb Red Cross (since 2012), a member of the Board of Neuroscience and Brain Diseases at the Department of Medical Sciences of the Croatian Academy of Sciences and Arts (since 2017) and a regular member of the Croatian Academy of Medical Sciences (from 2018).

Prof Jukić achieved much in helping psychiatrists and other psychiatry workers, especially while holding the position of the president of the Croatian Psychiatric Association (from 2010 to 2018). He was a member of the Committee for the Reorganization of Psychiatric Services in Croatia (1998-2001) and a working group of the same name (since 2001), as well as the State Committee for the Protection of Persons with 
Povjerenstva za reorganizaciju psihijatrijske službe u Hrvatskoj (1998.-2001.) i istoimene radne skupine (od 2001.), Državnog povjerenstva za zaštitu osoba s duševnim smetnjama (1998.-2015.), član Komisije za stručni nadzor Hrvatske liječničke komore (od 2005.), član povjerenstva Gradskog ureda za zdravstvo (i socijalnu skrb) za programe prevencije ovisnosti (1997.-2014.), član Savjeta za zdravlje Gradske skupštine Grada Zagreba (2010.-2015.), član Povjerenstva za psihijatriju Ministarstva zdravstva (u svim mandatima, od 1996. do 2018.)., član povjerenstva Ministarstva zdravstva za dodjelu zvanja primarijus (2004.-2011.), član povjerenstva (grupe za planiranje ljudskih resursa) Ministarstva zdravstva za izradu strategije razvoja zdravstva od 2012. do 2020. (od 2012.), član i predsjednik povjerenstva za izradu i praćenje provedbe strategije za zaštitu mentalnog zdravlja Ministarstva zdravstva (2017.-2018.), predsjednik povjerenstva za izradu i praćenje provedbe Nacionalne strategije zaštite mentalnog zdravlja od 2018. do 2030. (od 2018.).

Bio je član Povjerenstva za lijekove od 1993. do 2000., član upravnog odbora HLZ-a - Podružnica Zagreb i predsjednik Zagrebačke podružnice HLZ-a od 2004. do 2009., član Glavnog odbora predsjedništva HLZ-a te predsjednik Suda časti Hrvatskog liječničkog zbora (od 2013., reizabran 2017.), predsjednik skupštine Hrvatske liječničke komore (2011.-2015.), član predsjedništva Udruge poslodavaca u zdravstvu (od 1999.), njezin predsjednik od 2003. do 2013. dopredsjednik od 2013. Bio je jedan od osnivača i prvi predsjednik „Hrvatskog društva za psihijatriju i pravo“ (2003.-2008.), član izvršnog odbora HDPP-a (2008-2015).

Tijekom Domovinskog rata bio je jedan od glavnih organizatora psihijatrijske službe. Od 1991. do 1992. bio je zamjenik, a od 1992. pročelnik Odjela za duševno zdravlje Glavnog stožera Ministarstva zdravstva RH. Od 1995. bio je član kriznog stožera Ministarstva zdravstva RH.
Mental Issues (1998-2015), a member of the Commission for the Expert Supervision of the Croatian Medical Chamber (from 2005), a member of the Committee of the City Office of Health (and social services) for Addiction Prevention Programs (1997-2014), a member of the Health Advisory Board of the Zagreb City Council (20102015), member of the Committee for Psychiatry of the Ministry of Health (in all the mandates, from 1996 to 2018), a member of the Ministry of Health committee for selecting chief physicians (2004-2011), a member of the committee (of the human resources planning group) of the Ministry of Health for the planning of the National Health Care Strategy 2012-2020 (from 2012), a member and the president of the commission for the development and monitoring of the implementation of the strategy for the protection of mental health of the Ministry of Health (2017-2018), the president of the committee for the development and monitoring of the implementation of the National Strategy for the Protection of Mental Health 2018-2030 (since 2018).

He was a member of the Committee on Medication from 1993 to 2000, a member of the Management Board of the CPA chapter in Zagreb and the president of the Zagreb CPA chapter from 2004 to 2009, a member of the Main Board of the presidency of the CPA and the president of the Court of Honour of the Croatian Physicians Association (from 2013, re-elected in 2017). He was the president of the Council of the Croatian Medical Chamber (2011-2015), member of the presidential committee of the Croatian Health Employers Association (from 1999), its president from 2003 to 2013 and vice-president since 2013. He was one of the founders and the first president of the Croatian Association for Psychiatry and Law (CAPL) and the member of the executive board of CAPL (2008-2015).

During the Homeland War he was one of the main organizers of psychiatric services. From 1991 to 1992 he was the deputy, and since 1992 the head of the Department for Mental Health of the General Staff of the Ministry of Health of the Republic of Croatia. In 1995 he was a member of the Crisis Staff of the Ministry of Health of the Republic of Croatia. 
Zaslužio je mnoga priznanja: Spomenica domovinskog rata 1991., pohvala Predsjednika Republike dr. Franje Tuđmana za doprinos u obrani Domovine, medalja „Bljesak“, medalja „Oluja“, medalja „Ljeto 95“, odlikovanje Redom Danice Hrvatske s likom Katarine Zrinske (1996.), povelja, diploma, zahvalnica Ladislav Rakovac HLZ-a, Nagrada grada Zagreba 2008. godine.

Jedino što mu je bilo važnije od njegova posla bila je njegova obitelj. Supruga Branka, djeca Katarina, Mislav i Matija, unuci Juraj i Jona bili su mu radost i podrška. S njima je živio u skladu sa svojim vrijednostima. Nikad nije zaboravio od kuda potječe i uvijek je znao kamo ide. Krasila ga je nacionalna osviještenost, vjera, empatija i briga za bližnjega. Brinuo je za one koji pate, zalagao se za svakoga - i za psihijatra i za psihijatrijskog bolesnika.

Vlado Jukić je bio prije svega Čovjek. Bio je on i liječnik, psihijatar, forenzičar, primarijus, doktor znanosti, redoviti profesor u trajnom zvanju, ravnatelj, predsjednik Hrvatskog psihijatrijskog društva, autor i urednik knjiga, mentor i voditelj projekata. Ali, prije svega bio je dobar čovjek. I pošten čovjek. I velik.

Koliko god je sada teško svima koji smo ga poznavali is njim surađivali, koliko god smo sada tužni, možemo biti nadasve ponosni što smo živjeli s njim. On je svoj san ostvario, a mnogo je nas, njegovih suradnika, bolesnika, prijatelja, bilo dijelom toga sna.

Neki ljudi ne mogu umrijeti, jer su ostavili toliko dubok trag u srcima onih s kojima su živjeli, jer su ostavili toliko velika i snažna djela kroz koja će i dalje živjeti. Ti si, dragi Vlado, jedan od tih besmrtnih ljudi.

Zato, za sve što si napravio za hrvatsku psihijatriju, za hrvatsku psihijatrijsku publicistiku, za svoje Vrapče, za svoju Hrvatsku i za sve nas prijatelje, neka ti je vječna hvala.

Anđa Raič i Dražen Begić
He received many awards and commendations: 137 the Homeland War of 1991 Memorial, the Commendation of the President of the Republic Dr Franjo Tuđman for Contributions in the Defence of the Homeland, the "Bljesak" medal, the "Oluja" medal, the "Ljeto 95" medal, the Order of Danica Hrvatska with the Image of Katarina Zrinska (1996), the Ladislav Rakovac charter, certificate and letter of thanks of the CPA and the City of Zagreb Award in 2008.

The only thing that was more important to him than his work was his family. His wife Branka, his children Katarina, Mislav and Matija and grandchildren Juraj and Jona were a source of joy and support. He lived his life with them according to his values. He never forgot where he came from and always knew where he was going. Prof Jukić was marked by a patriotic sensibility, faith, empathy and care for his fellow man. He cared for those who suffered, and advocated for everyone - both psychiatrists and psychiatric patients.

Vlado Jukić was above all a Human Being. He was a physician, psychiatrist, forensic expert, chief physician, Doctor of Philosophy, tenured full professor, hospital director, the president of the Croatian Psychiatric Association, an author and editor of books and a mentor and project leader. But above all that, he was a good man. And an honest man. And a great one.

As hard as it is now for everyone who knew him and worked with him, as sad as we now are, we can be proud that we lived with him. He had achieved his dream, and many of us, his colleagues, patients, friends, were part of that dream.

Some people cannot die, because they have left such a deep mark on the hearts of those they have lived with, because they have left such great and powerful works that will live on. You, dear Vlado, are one of these immortals.

Thus, for everything you have done for Croatian psychiatry, for Croatian psychiatric publishing, for your Vrapče Hospital, for your Croatian homeland and for us your friends, we will be eternally grateful.

Anđa Raič i Dražen Begić 